\title{
College Innovating Entrepreneurship Education Routes Research Based on TRIZ Theory ${ }^{1}$
}

\author{
Zhao $\mathrm{Na}^{2}$, Chen Long ${ }^{3}$, Sun Hongxia ${ }^{4}$ \\ Nantong University Xinglin College
}

*Corresponding Author: Zhao Na, Nantong University Xinglin College.

\begin{abstract}
Many universities are researching routes about implementation of innovating entrepreneurship education. What's more, as the theory of discovering problem and solving problem, TRIZ theory becomes more and more important and is now applied in many areas. Based on researches, this article utilizes TRIZ theory and puts out analysis one about goods and scene: to perfect the first class. It also put out analysis two: school and company's collaboration; conflict analysis: to uplift students comprehensive quality; to lead the TRIZ theory into class teaching.
\end{abstract}

Keywords: TRIZ; innovating entrepreneurship; goods and scenes analysis; conflict analysis

Now our country is in the situation of changing its type. It is changing from the conventional economic society to knowledge-based society. The international competition nowadays is almost talents' competition. The talents' competitions focus on the level of innovation and starting one's business. Compared to develop countries, though our innovating entrepreneurship starts late, the government starts to put more and more attention in it. The government punished < the Plan of Developing Education Faced to 21 Century> in 1999. It also proposed that to strengthen the entrepreneurship education of teachers and students and encourages them to set up high and new tech enterprises. The innovation education research program of National Academy of Education in 2004 officially started. By carrying out innovation education, the government cultivates students' creative qualities and lays foundations for cultivating high quality innovative talents. In 2010, Education Department published $<$ the views about putting efforts to promote colleges innovating entrepreneurship education and self-employment work by college students>. In November, minister yuan stressed that all colleges should try their best to achieve success in the part of students' self-employment. Colleges ought to improve students' innovation spirit and entrepreneur ability. In 2015, the State Department pointed out policies about putting efforts to push on innovation and entrepreneur. Development is the origin of motive power and it is also the way for people to become rich. It is the method of making society impartial and the way to build the country. It is not only good for pushing the changes of economic structure and building a new engine, but also has important significance for strengthening the development of new power and taking the road of innovation and development. It makes the consumption raise and enlarges the number of jobs. It can stimulate the wisdom and creativity of many people and promote society vertical mobility and fairness and justice.

\footnotetext{
${ }^{1}$ Level of subject: colleges and universities in jiangsu province department of education philosophy and social science fund; Project name: entrepreneurship education in colleges and universities based on the theory of TRIZ innovation path exploration; Number: 2016SJD710232

${ }^{2}$ Zhao na (1982.03), female, han ethnic group, native of shandong binzhou people, master of law, lecturer, in the student thought political education work.

${ }^{3}$ Chen Long (1977.04), male and Han, native of Jiangsu, Haian, applied psychology master, associate professor, engaged in Ideological and political education of students

${ }^{4}$ Sun Hongxia (1985.10), female and Han nationality, native of Jiangsu, Nantong, master of management, engaged in higher education administration
} 


\section{The CONNOTATION AND SIGNIFICANCE OF COLLEGES' INNOVATING ENTREPRENEUR EDUCATION}

\subsection{The Connotation of Colleges' Innovating Entrepreneur Education}

The innovating entrepreneur education is a kind of new education thought appears with knowledge economic era. < the views> gives the formulations of innovating entrepreneur education and shows that our ministry of education works and starts both from the conditions of college education and the development of medium and long education. But innovating entrepreneur education is a high indistinct concept. There are many talks about it. The main thought is the cultivation of the creative entrepreneur, creative consciousness, entrepreneur quality, exercise ability and the development of students' creative personalities, insistence, spreading thoughts, and venture spirit. Generally speaking, creative entrepreneur education has the requirement of knowledge, skill psychological quality. It is the kind of concrete and pragmatic education.

\subsection{The Significance of Colleges' Innovating Entrepreneur Education}

\subsubsection{Need for Building Creative Country}

Creative ability is the decisive factor for a country or a nation to develop. Though our country has changed a lot in the type of economic increase and industry structure. Compared with developed country, our country still falls behind western countries. According to authoritative statistics, our country's scientific and technical payoffs percent conversion is $6 \%$ to $8 \%$ and the developed country is about 50\%. Therefore, the eighteenth national congress of the CPC puts out that we must actualize the creative driven development strategy. We should put the technological innovation at the first place and build an innovative country. Take the road of socialism with Chinese characteristics is to take the capability of independent innovation as the national strategy. Cultivating high level innovating talents and forming the mechanism that is good for self-creation. To build a creative country, the key is to cultivate creative talents, the basis is to strengthen innovating entrepreneur education. So our country must uplift the creative sense and entrepreneur ability and strengthen innovating entrepreneur education.

\subsubsection{Need for Colleges' Development and Reform}

Colleges are the main place for cultivating talents. It is colleges' mission to develop people's potential proficiency and increase people's comprehension ability. After enlarging the number of college students, facing the stern test of finding a job, our country's education is staying at the zero hour that transforming from extension to connotation development. So colleges must recognize the shortages of themselves, overcome the shortages and bring the advantages in to play. Starting the scientific research and teaching around basic function of cultivating colleges' talents and increase the quality of talents. All these are served for area economic development and creative country. So colleges' should deepen the reform and take starting one's ability as the aim, take the entrepreneur spirit as the key, take task as the carrier and let innovating entrepreneur education throughout the whole process and finally make some contribution for the country.

\subsubsection{Need for Uplift Students' Comprehension Quality}

Innovating entrepreneur education is the way to cultivate students' creative thoughts, spirit and increase their ability. So they can become talents who has divergent thinking. They are able to present problems and finally become pioneering talents. Therefore, innovating entrepreneur education is not only a way to relieve the hard condition of finding jobs, but also can uplift students' comprehension ability, let students have a better future and finally uplift all people's qualities. As a word, cultivating high comprehension quality talents is also the need for international competition.

\section{TRIZ CORRELATION THEORY}

TRIZ is freely translated into the solution theory of inventive problem. It successfully reveals the inherent law and principle of creation and invention, and focuses on clarifying and emphasizing the contradictions in the system, the goal is to completely solve the contradiction and get the final ideal solution. It does not take the compromise approach, it is based on the law of development and evolution 
of technology to study the whole design and development process instead of random behavior. Practice has proved that the use of TRIZ theory can greatly accelerate the process of creation of people and can get high quality innovative products. In this paper, we use the "substance-field analysis" and "system conflict analysis" in TRIZ theory.

Substance-field analysis is a method based on the analysis of the technological creation caused by the interaction among the components of the technical system. The analysis holds that any function can be broken up into three basic elements, so it can be inferred that a function must have three basic elements which must be suitable that the function to be able to exist. System conflict is one of the core elements of TRIZ, which indicates the inherent contradiction hidden behind the problem.TRIZ argues that the solution of the creative problem is to solve at least one conflict. TRIZ has two kinds of conflicts, one is technical conflict, the other is physical conflict. Technical conflict refers to the improvement of a certain aspect of the system, on the other hand, there will be no wanted result. Physical conflict refers to the two opposite states of the system appeared at the same time, TRIZ uses the separation of time and space to solve the physical conflict.

\section{The Problem ANALYSIS AND SUgGeSTIONS By USING TRIZ THEORY}

\subsection{Substance- Field Analysis: To Improve the First Class}

Colleges and universities (F) should act on S1 (college students) through S2 (innovation and entrepreneurship courses). However, the traditional classroom teaching do not take the innovation and entrepreneurship education as the first class teaching content, is not organically linked with professional education to form a scientific and perfect teaching system of innovation, and has no clear Innovation and entrepreneurship education objectives and complete teaching plan. Innovation and entrepreneurship education in most schools, mainly dependent on the course of employment guidance and lack specialized practice and education curriculum system for College Students which mostly stay at the level of guiding students to participate in the competition of business planning, the lectures and competitions they hold are all temporary activities. On the one hand, few students which are usually the elites will take part in these activities; on the other hand, it is difficult to stimulate innovative thinking and enhance students' quality of innovation and entrepreneurship. Therefore, I use the general solution of substance- field analysis in TRIZ theory, to add elements, increase material S2 (innovation and entrepreneurship courses), and finally to constitute a complete model (As Figure 1). In the questionnaire, $89 \%$ of the students think that the school should set up a special course of innovation and entrepreneurship, and are willing to participate in learning. So that the innovation and entrepreneurship education can cover the majority of students, cultivate students' innovative thinking, thereby enhance the ability of innovation and entrepreneurship.

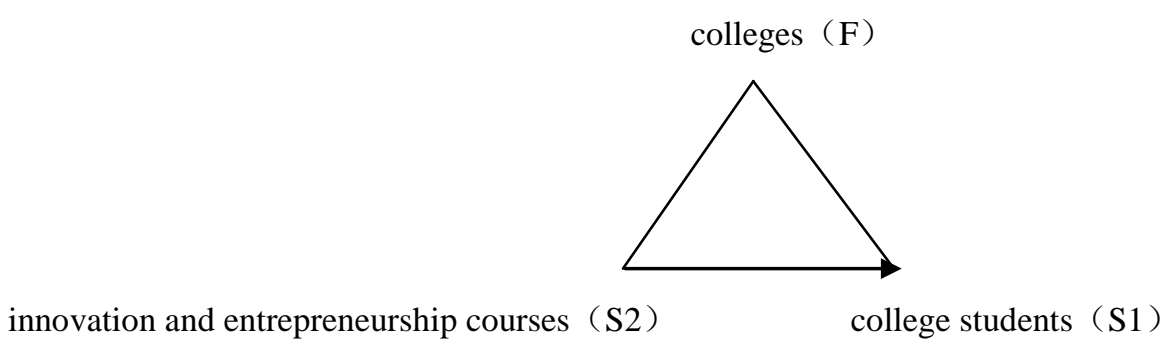

Figure1.

\subsection{Material - Field Analysis: To Carry out the Second Classroom, Cooperation between School and Enterprise and Enhance the Sense of Innovation}

In colleges and universities (F), S2 (innovation and entrepreneurship courses), S1 (college students), besides the object - field model ,colleges and universities should strengthen cooperation between enterprises and enhance students to participate in practice and give them opportunities to broaden their way to the practice. On the one hand, the relevant professional successful entrepreneurs should come to 
the students to carry out their own experiences, cooperate the enterprise's all-real business environment into the university, so that students can understand the market and customers, while provide innovative business projects and guide innovative to students. $79 \%$ of the respondents in this questionnaire ask the school to invite successful people to talk about their experience. On the other hand, the students should go out to visit, research, practice. The rational analysis of society and the market and the correct understanding can help them improve the creative initiative of the entrepreneurial power. $86 \%$ of students hope that the school can organize students to visit the field base. That is, the formation of F1 (business), S3 (second class), S1 (college students) - field model and the first classroom (Figure 2) 86\% of the students in this questionnaire hope schools to establish school-enterprise joint venture base to enhance students' awareness of innovation and entrepreneurship, and improve students' ability of innovation and entrepreneurship.
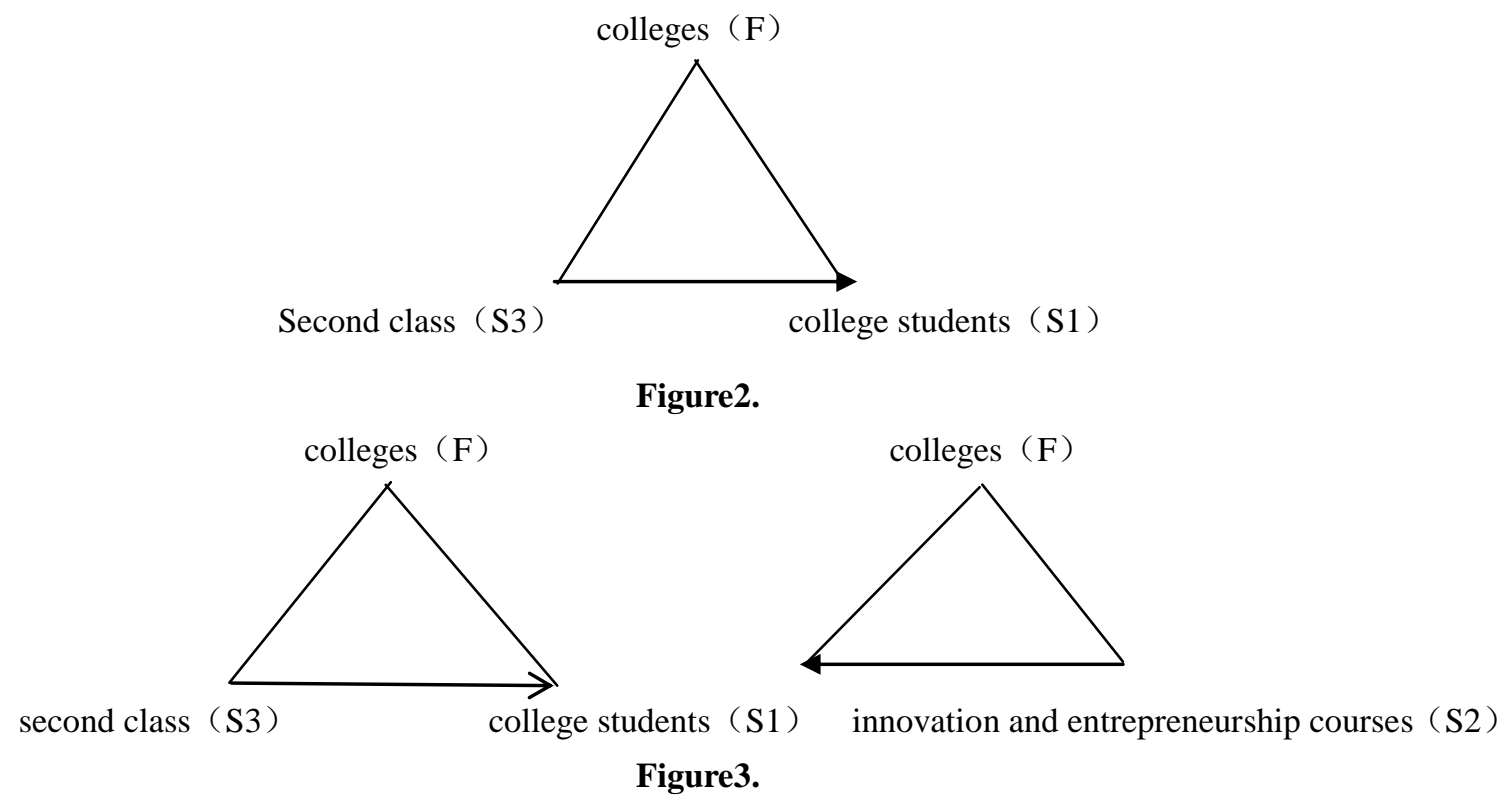

Figure2.

Figure3.

\subsection{TRIZ Theory in the Classroom Teaching}

TRIZ theory as a new invention theory to solve problem. It should also be introduced into the teaching of innovation and entrepreneurship in colleges and universities and change the traditional boring duck infusion theory. Through case teaching, practice teaching to guide students to think positively, combined with TRIZ 40 innovative principles, we can carry out project discussion, and train students thinking. Of course, this requires proficiency in the TRIZ theory. Therefore, the teacher on the one hand should carry out innovation and entrepreneurship theory study, on the other hand they have to carry out training, personally participate in entrepreneurial activities and improve practical experience.

\subsection{Conflict Analysis: Improve the Overall Quality of Students}

In the education system, professional education and general education as two subsystems have contradictions and conflicts. Professional education is a single area of the required expertise and skills, and general education emphasizes the overall quality of students. In a certain Professional education, general education courses are generally less than professional courses, but this education model lead to the interdisciplinary, professional links between the isolation. The student's knowledge structure is limited; innovation and entrepreneurship cannot be improved. $75 \%$ of the students in this survey believe that the current expertise cannot meet their entrepreneurial needs. However, only the mastery of knowledge, for entrepreneurs, is far from enough, innovators also need a wider range of general knowledge, such as laws and regulations, interpersonal communication, customer management, innovative thinking methods and other knowledge. In this survey, $66 \%$ of the students hope to improve their communication skills; $58 \%$ of students hope to improve their market insight. Therefore, as a university, the innovation and entrepreneurship education should be treated equally, so that they can be in the best condition for college students to improve innovation and entrepreneurship to lay the 
foundation.

\section{REFERENCES}

[1] Yu jianxiu, Zhang jing. Scientific orientation and method analysis of innovation and entrepreneurship education in colleges and universities. Journal of BaoDin academy. 2012.9, p115

[2] Xiang Lei, Thinking on furtherance of innovation and entrepreneurship education in colleges and universities, Ideological and Theoretical Education, 2014.6 , P90

[3] Li Hongxia, Research on controlling factor of university students' ability of innovation and entrepreneurship, Master's thesis of Xi'an University of Science and Technology.

[4] Sun qinxiu, Gao Hanfeng, Significance and Practice of innovation and entrepreneurship education in colleges and universities, Innovation and Entrepreneurship Education. 2013.8,P49

[5] Kodak· carlson, wiliam· wilmot, Innovation.Beijing Normal University Press, 2007.

\section{AUTHORS' BIOGRAPHY}

Zhao Na (1982.03), female, han ethnic group, native of shandong binzhou people, master of law, lecturer, in the student thought political education work.

Chen Long (1977.04), male and Han, native of Jiangsu, Haian, applied psychology master, associate professor, engaged in Ideological and political education of students

Sun Hongxia (1985.10), female and Han nationality, native of Jiangsu, Nantong, master of management, engaged in higher education administration

Citation: Zhao Na, Chen Long, Sun Hongxia, College innovating entrepreneurship education routes research based on TRIZ theory, International Journal of Humanities Social Sciences and Education (IJHSSE), vol 4, no.9, 2017, pp. 8-12. doi:dx. doi.org/10.20431/2349-0381.0409002.

Copyright: () 2017 Authors. This is an open-access article distributed under the terms of the Creative Commons Attribution License, which permits unrestricted use, distribution, and reproduction in any medium, provided the original author and source are credited. 